\title{
English distance learning: possibilities and limitations of MEO for the Flipped Classroom
}

\section{Aprendendo Inglês à distância: possibilidades e limitaçôes do MEO para a Sala de Aula Invertida}

Kyria Rebeca Finardi*

Universidade Federal do Espírito Santo

Vitória - Espírito Santo / Brasil

Gicele Vergine Vieira Prebianca**

Instituto Federal de Educação, Ciência e Tecnologia Catarinense

Blumenau - Santa Catarina / Brasil

Jeovani Schmitt ${ }^{* * *}$

Instituto Federal de Educação, Ciência e Tecnologia Catarinense

Blumenau - Santa Catarina / Brasil

\begin{abstract}
The study investigates possibilities and limitations of the course My English Online (MEO) for the inverted classroom format. Two hundred and eighty-nine Brazilian federal university students evaluated the MEO software in terms of usability features. Three participants were interviewed for data triangulation. Results of the study suggest that users with more experience are more sensitive to aspects of human-computer interaction than less experienced ones, particularly when the criteria of Flexibility, User Experience, Informational Density and Feedback are considered. In addition, findings also show that the speaking and writing skills are the most difficult to develop in the MEO course. The study concludes that, in order to overcome limitations in MEO, especially in terms of the Feedback criterion, the software can and should be used in the flipped classroom format.
\end{abstract}

KEYWORDS: online L2 teaching and learning; MEO; flipped classroom.

\footnotetext{
*kyria.finardi@gmail.com

**gicele.prebianca@blumenau.ifc.edu.br

***jeovani.schmitt@blumenau.ifc.edu.br
} 


\begin{abstract}
RESUMO: O estudo investiga as possibilidades e limitações do curso My English Online (MEO) para a sala de aula invertida. Duzentos e oitenta e nove participantes avaliaram o software em termos de características de usabilidade. Três participantes foram entrevistados para a triangulação de dados. Os resultados sugerem que usuários mais experientes são mais sensíveis aos aspectos de interação humano-computador do que usuários menos experientes, particularmente quando os critérios Flexibilidade, Experiência do Usuário, Densidade Informacional e Feedback são considerados. Os resultados também mostraram que as habilidades de fala e escrita são as mais difíceis de desenvolver no MEO. O estudo conclui que as limitações do MEO, especialmente em relação ao critério Feedback, podem ser superadas se ele for usado no formato de sala de aula invertida.
\end{abstract}

PALAVRAS-CHAVE: ensino-aprendizagem de inglês à distância; MEO; sala de aula invertida

\title{
1 Introduction
}

Brazilians have recently witnessed some State initiatives for the internationalization of higher education. These actions have focused mainly on increasing the number of scholarships offered to boost international academic mobility of Brazilian universities. To this end, in July 2011 the Ministry of Education created the Science Without Borders (CsF) program in order to promote technological and scientific development through the exchange of students and researchers with world-class institutions. However, despite the over 100,000 scholarships offered, most university students were not eligible for the program due to their low level of proficiency in English. As a result, the English without Borders program was created in 2012 to promote English learning through three main actions offered free of charge for the university community: 1) in-person courses held by NucLis (English language centers) established in federal universities with English teachers who receive scholarships from CAPES; 2) the administration of TOEFL ITP tests in universities and higher education institutes, and 3) an English online course, the My English Online (MEO). The current demand for the implementation of a program of this kind in order to encourage the internationalization of higher education in the country confirms the dire need to correct a historical deficiency in English language teaching in Brazil.

Some authors (e.g., TILIO, 2014) understand that the public school does not have to train fluent speakers of foreign languages, just as the school does not have the responsibility to train mathematicians, physicists or biologists for that matter. However, we disagree with this expectation 
of public education and think that it is possible to train fluent speakers of foreign languages in public schools, as has been shown in many countries (e.g., HOFFMANN, 2000, on multilingualism and English education in Europe; MUÑOZ, 2000, on bi and trilingualism in Cataluña; LASAGABASTER, 2000 on bi and trilingualism in the Basque country; BJORKLUND; SUNTI, 2000, on English and Swedish learning in Finland; YTSMA, 2000, on trilingual education in Friesland; IACTU, 2000, on the learning of foreign languages in Hungary, Romania; CSILLAGH, forthcoming, on the learning of national and foreign languages in Switzerland).

After two years of its implementation, the MEO course is still an underutilized tool in some educational institutions and little is known about the possible contributions and/or limitations of this technological tool for language learning. Despite the many appeals and incentives to use technology in education, especially in teaching English as a foreign language (e.g., FINARDI, 2012; FINARDI; PREBIANCA; MOMM, 2013; FINARDI; PORCINO, 2014; FINARDI; TEIXEIRA; PREBIANCA; DOS SANTOS JÚNIOR, 2014; PREBIANCA; CARDOSO; FINARDI, 2014; PREBIANCA; FINARDI; CARDOSO, 2015), it is worth questioning, from a pedagogical perspective, the validity of the MEO in the development of the aspects involved in learning an additional language (L2), especially in terms of the development of speaking. As pointed out by Xhafaj and Prebianca (2006), it is not uncommon to find L2 learners with a vast knowledge of lexicon and grammar rules yet unable to verbally express themselves in that language. According to the authors, "The desire to speak another language, and what is more, to speak it fluently is often the ideal that drives most people who decide to learn a foreign language" (p. 1).

Notwithstanding the desire to speak another language fluently, English teaching in public schools seems to fall short of this expectation in Brazil, where most teaching practices focus primarily on the development of the reading ability (e.g., TILIO, 2014; SILVEIRA, 2015), which also seems to be the case with MEO, since important aspects of learning a L2, such as the productive skills (speaking and writing), are not properly operationalized in this distance learning course as pointed out by Finardi, Prebianca, Schmitt and Andrade (2014).

School can no longer be conceived as a space for the production of knowledge decontextualized from the influence of technology in the globalized world we live in. However, although widely equipped with computers and computer labs, schools (we mean mostly teachers) do not 
seem to make the most of the pedagogical potential of these tools (e.g., PREBIANCA; CARDOSO; FINARDI, 2014; TEIXEIRA; FINARDI, 2013). According to Finardi, Teixeira, Prebianca and dos Santos Junior (2014), this is due to the fact that many teachers still believe that preparing new teaching-learning materials, booking equipment and carefully selecting the most appropriate technological tool for a given session equals more time spent planning and teaching. In other words, the use of new technologies can be seen by some teachers as extra workload and a pedagogical practice often impractical and inconsistent with the investment in the teaching profession in Brazil.

However, Finardi, Teixeira, Prebianca and dos Santos Junior (2014) showed that, contrary to what teachers may think regarding the use of new technologies in education, undergraduate students believe that a technological approach, particularly for teaching English, allows greater interaction in the language and renders the learning experience more dynamic and motivating. In short, the study suggested, among other things, that there is a gap between students' needs and expectations and teachers' beliefs regarding the use of technologies for L2 teaching-learning.

Thus, the search for new teaching methods that can meet teachers' and students' expectations and ensure learning is therefore a real need in the current educational landscape. One possibility of enhancing the use of new technologies for educational purposes is the implementation of the method known as inverted classroom or flipped classroom. The concept of inverted classroom was presented by J. Wesley Baker in the $11^{\text {th }}$ International Conference on School of Teaching and Learning in Florida in 2000.

In the seminal article on the concept of inverted classroom, Lage, Platt and Tregial (2000) claim that the results of their research coupled with their teaching experiences indicate a mismatch between teachers' teaching style and students' learning style, often resulting in low motivation and poor learning experiences. The authors also suggest that there are essentially three general classification systems for these styles. The first system ranks learning styles as dependent, collaborative or independent. Dependent learners require a lot of direct instruction from the teacher, while collaborative students prefer working as part of a team and independent learners are better off left on their own. According to the authors, there is evidence that the greater the divergence between teaching and learning styles, the worse the learning outcomes will be. 
The second classification system reviewed by the authors is based on personality types measured by the Myers-Briggs Type Indicator, which classifies individuals by four different personality scales. The scales correspond to how the individual relates to the world (introverted $\mathrm{x}$ extrovert); processes information (sensing $\mathrm{x}$ intuitive); makes decisions (thinking $\mathrm{x}$ feeling); and evaluates the environment (judging $\mathrm{x}$ perceiving). These personality traits affect an individual's learning style and again Lage, Platt and Tregial (2000) cite research findings that corroborate their hypothesis that when there is convergence between learning and teaching styles, learning is improved.

The third learning style classification focuses on how students receive and process information. Based on two criteria, students are divided into four categories: assimilators, converters, diverters, and acommodators. Assimilators and converters process information through abstract conceptualization, while diverters and acommodators process information through concrete experiences. Converters and acommodators process information through active experimentation, whereas diverters and assimilators process information through observation and reflection.

Based on these classification systems, Lage, Platt and Tregial (2000) suggest a teaching approach that can suit all types of styles. The method described by the authors (the inverted classroom) uses a variety of teaching styles, but they all have the media as a common ground and cornerstone, since, according to the authors, multimedia course material presentation optimizes learning opportunities, allowing students to perform better based on their own mix of skills and learning styles.

Also according to these authors, the concept of inverted classroom assumes that events traditionally taking place inside the classroom take place outside and vice versa (LAGE; PLATT; TREGIAL, 2000, p. 32). In an experience with this method at the University of Miami, students should read the course content (available through multimedia resources) before class to be ready to discuss it in class. To begin the lesson, teachers asked students if they had any questions about the material read. If there were questions, a mini lecture of about 10 minutes was held to address the questions. If there were no questions, students were told that the lack of questions would be interpreted as a sign that they had understood the content. After this step, students and teacher would go to the laboratory, where they could put into practice the principles studied. The rest of the 
class was devoted to practical experiments, checking of exercises and review of questions and contents.

Based on the assumptions of the inverted classroom method and motivated by the fact that MEO, although created to promote the full learning of English (i.e., developing the four skills), does not seem to contribute to the development of the productive skills of writing and speaking, as shown in Finardi, Prebianca, Schmitt and Andrade (2014), this study aims to analyze the possibilities and constraints of MEO for a blended approach where traditional practices can be combined with the online course to meet the requirements of the educational scenario of the $21^{\text {st }}$ century.

Aware of the difficulty of implementing a technological tool that fosters the development of the productive skills in additional languages, we think that MEO could be better explored in a hybrid learning environment with the inverted classroom method, allowing students to acquire grammar rules and vocabulary, through various genres, in the distance mode, and practicing oral and written skills in physical classrooms, focusing on the interaction and meaning making through production activities with pedagogic mediation and teacher feedback when necessary.

Considering the potential of inverting the classroom as a backdrop for the optimization of $\mathrm{MEO}$ resources, this study was guided by the following research question: "What is the potential of MEO for the inverted classroom, considering the human-computer aspects of interaction in the software?" The importance of analyzing large scale human-computer interaction aspects of MEO relies in the fact that, as argued by Prebianca, Vieira and Finardi (2014b), educational software programs such as MEO can mediate the interaction between linguistic stimulation and learners, allowing the latter to create new mental connections from significant learning experiences that will enable them to transcend their current cognitive stage during problem solving and the execution of increasingly more cognitively complex tasks. This means that those mediated experiences, as long as they are pedagogically and clearly defined, can be meaningful and therefore boost the transcendence of knowledge, which in turn may lead to structural cognitive modifiability, as recommended by Feuerstein and Feuerstein (1994) and Feuerstein (1997). In this sense, Prebianca, Vieira and Finardi (2014b) suggest that any educational software whose purpose is to promote the learning of an additional language, should, among other things, incorporate the pedagogical features of mediated learning experiences (intentionality, 
meaning and transcendence) as well as the concern with learners' prior knowledge, language needs and mental models of reasoning, without which the propensity to structural cognitive modifiability (learning) may be jeopardized.

As Finardi and Porcino (2014) remind us, the teaching of English has always been linked to the use of technology, though after the advent of the Internet, technologies no longer have a role of simple pedagogical support, but rather occupy a central place in the use, teaching and learning of languages. In relation to English teaching and learning through educational software programs, Prebianca, Vieira and Finardi (2014b) analyzed the perceptions of learners of English as a foreign language on the use of the educational software Interchange Arcade in the light of the theory of Structural Cognitive Modifiability (FEURSTEIN, 1994; FEUERSTEIN; FEUERSTEIN, 1997). Data were collected through questionnaires before and after using the software. In general, the qualitative analysis of students' views showed that the software was seen as an important learning tool, but the ergonomic analysis showed that some human-computer interaction features must be revised to allow a convergence between the pedagogical and ergonomic features of the online platform. Based on the theory of structural cognitive modifiability, the authors concluded that the quality of the software mediation is an important factor in the use of technology to promote the learning of additional languages. The study suggested that factors such as intentionality, transcendence and meaning are not reflected in the human-computer interaction characteristics of the software, thus hindering the desired structural cognitive modification - in this case, the language learning.

With specific reference to online English learning, several studies (e.g., FINARDI, 2012; PREBIANCA; VIEIRA; FINARDI, 2014a; PREBIANCA; CARDOSO; FINARDI, 2014; PREBIANCA; FINARDI; CARDOSO, 2015) point to the benefit of using hybrid methodologies combining faceto-face classes with online instruction, which can be implemented at the level of activity, program or institution (GRAHAM, 2005). In this sense, Silveira (2015) investigated the impact of a hybrid approach to English language teaching in an intact classroom at the Brazilian Naval School in the level of the activity. In her study, Silveira adapted pedagogical tasks, designed by Finardi and Porcino (2013), using online tools to develop digital literacy and communication skills in English in a hybrid approach. Overall, results of her 
study revealed that the blended approach implemented may contribute to language development and digital literacy, encouraging autonomy, motivation and prolonged contact in and with the target language.

In another study, Finardi, Prebianca, Schmitt and Andrade (2014) discussed the impact of technology and the internationalization of education in teaching and learning English by analyzing students' perceptions of MEO. The analysis showed that MEO is not enough to promote full language learning, since the software does not cater for some important aspects of language learning. According to the evaluations of participants, the oral skill is the most challenging and difficult to develop in MEO because the stimulus offered by the course seems to be insufficient to promote interaction and significant oral practice in English. Another negative aspect pointed out by the participants refers to the lack of correction of written texts and audio recording, which hinders learning because students do not know their possible errors and how to fix them. Finally, with respect to the ergonomic features of the software, results of their study concluded that the lack of pedagogical feedback is a negative feature. In addition, there was a weak relationship between the pedagogical and ergonomic features of the course, corroborating Prebianca, Vieira and Finardi (2014b).

Having outlined this panorama, we conclude that: (1) hybrid/blended approaches seem to be the best option for English teaching and learning; (2) the Internet and online educational resources play a central role in the development of language skills in another language when complemented by methods that support the development of productive skills like speaking and writing; and (3) MEO is a relevant option for learning English, but it needs to be combined with a teaching method (the inverted classroom seems to be the ideal option) that favors a suitable pedagogical feedback, providing a moment of interaction and meaning making, which is essential for full language development. Thus, in order to reflect on the potential of MEO for English teaching and learning in a hybrid environment implemented in the inverted classroom mode, the following section provides a detailed description of the contents and objectives of each level of MEO.

\section{The My English Online course}

As previously mentioned, MEO is one of the actions of the English without Borders (EwB) program, proposed by the Ministry of Education in partnership with SESU and CAPES. It is worth mentioning that of the 
three EwB actions, only two are available to all university students, namely TOEFL ITP tests and MEO. The face-to-face English classes offered by NucLis are limited to the size and capacity of each NucLi, varying and depending on the size of each higher education institution. By way of illustration, at the Federal University of Espirito Santo, MEO and TOEFL are available to almost 30,000 academics (approximately 26,000 students, 3,000 teachers and 1,000 staff) but only 480 vacancies are offered for the NucLi face-to-face classes.

Structurally, MEO is divided into five levels of proficiency. The material includes e-books with content geared to the development of reading, writing, reading comprehension, oral and grammar skills. The software offers authentic materials from the National Geographic database for the development of reading ability and videos for the development of listening. At the end of each part, the user (student) makes a progress test in preparation for the final test of the final level.

On the first level it is expected that students can, at the end of the unit, carry out the following actions: greeting colleagues, saying and writing telephone numbers and following classroom instructions (Pre Unit); identifying colleagues, talking about nationality and marital status, saying and writing addresses and saying and writing dates (Unit 1); presenting their colleagues, describing their classroom, identifying classroom activities, talking about hours and describing the weather (Unit 2); identifying common foods, talking about hunger, talking about quantity, making a shopping list and expressing preferences (Unit 3); identifying types of clothing, identifying and finding sessions in a store, identifying colors and describing clothing, shopping, counting money and reading advertisements (Unit 4); identifying and discussing locals, describing houses, identifying types of shipping, expressing shipping preferences and giving and following directions (Unit 5); identifying body parts, describing symptoms and diseases, identifying medicines, describing healthy habits and identifying actions in the waiting room (Unit 6); identifying work, giving information on work, identifying job responsibilities, reading reviews and signs and following directions (Unit 7); organizing study materials, shopping, giving and following directions, accomplishing goals and developing a program of study (Unit 8).

On the second level it is expected that students can, at the end of the unit, carry out the following actions: greeting colleagues, saying and writing phone numbers and following classroom instructions (Unit 1); identifying 
and talking about work, talking about countries and comparing work in different countries (Unit 2); identifying and describing a comfortable home and identifying objects (Unit 3); identifying personal items, talking about possession, purchasing a gift and identifying a particular office (Unit 4); talking and asking about daily activities, talking about what they do at work and reading and writing job descriptions (Unit 5); following directions, reading and using a map, talking about transportation and recording a journey (Unit 6); identifying activities, talking about favorite activities, discussing skills and describing sports activities (Unit 7); identifying types of clothes, shopping, identifying colors and describing clothes, reading about manufacturing clothing (Unit 8); ordering a meal, planning a party, expressing amounts, quantifying and interpreting food and nutritional needs (Unit 9); identifying parts of the body, describing symptoms and diseases, identifying medicines and treatments, describing alternative medicine treatments (Unit 10); making appointments, understanding and using a calendar, talking about special events and describing a special occasion (Unit 11); talking about past holidays, discussing the pros and cons of adventure travelling, describing the weather in vacations, talking about special holidays (Unit 12); meeting people, asking and giving personal information, describing different jobs, talking about people and their work (Unit 13); talking about a day's work, talking about their leisure time, describing a festival or celebration, comparing different festivals (Unit 14); asking and giving personal travel information, giving travel advice, sharing travel tips (Unit 15); talking about food, ordering a meal, talking about diets and discussing favorite and different foods (Unit 16).

On the third level it is expected that students can, at the end of the unit, carry out the following actions: talking about sports activities taking place now, comparing present and daily activities, talking about favorite sports, discussing adventure holidays (Unit 1); talking about past holiday trips, exchanging information on vacation, using was/were to describe personal experiences, talking about a past discovery (Unit 2); talking about personal communication, writing contact details, describing characteristics and qualities, comparing different types of communication (Unit 3); talking about plans, discussing long and short term plans, describing the weather, discussing the future (Unit 4); making comparisons, explaining preferences, talking about clothing materials, understanding and describing a process (Unit 5); giving advice on healthy habits, suggesting ways to improve bad 
habits, asking about lifestyles, evaluating their lifestyle (Unit 6); talking about jobs, being interviewed for a job, talking about life achievements, discussing scientific achievements (Unit 7); talking about money management, choosing how to spend money, talking about how actions can have positive consequences, discussing ways to prevent destructive habits (Unit 8); comparing what people used to do and what they do now, identifying regional foods, talking about traditional dishes, understanding how a regional dish becomes an international dish (Unit 9); communicating with people, talking to strangers, breaking the ice, learning how professionals speak (Unit 10); describing their city, talking about a good neighborhood, discussing a plan of action, predicting cities in the future (Unit 11); discussing ways to be healthy, talking about lifestyles, suggesting natural medicines, understanding how bacteria affects the body (Unit 12); talking about challenges, reflecting on past accomplishments, using too/enough to talk about ability, describing a personal challenge (Unit 13); using the past to talk about milestones in life, talking about the best age to do something, making questions using more information, describing major transitions in life (Unit 14); explaining how to get luxury items, talking about needs and wants, discussing what makes people's lives better, assessing the way that advertising creates desire for products (Unit 15); using the conditional to talk about real situations, talking about possible future situations, describing what animals do, giving opinions about problems in nature (Unit 16).

On the fourth level it is expected that students can, at the end of the unit, carry out the following actions: discussing life in the past, talking about grandparents, comparing ways of doing things in the present and in the past, considering the impact of the "Columbian Exchange" (Unit 1); talking about preparations for a trip, talking about different types of holidays, using English in an airport, discussing the pros and cons of tourism (Unit 2); discussing career choices, asking and answering questions related to work, talking about career plans, identifying career qualifications (Unit 3); describing a festival, comparing holidays in different countries, talking about personal celebrations, sharing holiday traditions (Unit 4); discussing the impact of weather in our lives, talking about chronic and severe weather conditions, giving reasons for planned actions, understanding a sequence of events (Unit 5); talking about remembering and forgetting, talking about senses, describing an emotional experience (Unit 6); giving strength to statements and opinions, distinguishing facts and prejudices, explaining 
cause and effect of natural phenomena, sharing a personal opinion about an important cause (Unit 7); describing financial habits, talking about types of money used in the past, using English for banking activities, talking about wealth (Unit 8); expressing possible cause and effect, discussing personal reactions in survival situations, talking about regrets, showing admiration for rescue workers (Unit 9); reporting what someone else said, explaining views on art, discussing favorite movies, talking about public art (Unit 10); talking about advances in transportation, talking about choices in transportation, using English to get around, making recommendations to improve transportation (Unit 11); giving additional information, understanding and sharing information about sports, discussing personal competitive experiences, rooting in sports (Unit 12); arguing that things are dangerous, talking about dangerous work, talking about emergencies, describing a situation in which they were at risk (Unit 13); giving possible explanations, interpreting reports, expressing belief or disbelief, reporting a local mystery (Unit 14); talking about plans and educational decisions, talking about learning style, discussing a university degree, sharing personal suggestions to improve schools (Unit 15); talking about the future, understanding and reporting specific facts, discussing advantages and disadvantages of an action, giving and sustaining a review and opinion (Unit 16).

The fifth and final level of MEO is divided into three parts, each of which aims to prepare students for one of these proficiency tests in English: (1) TOEFL - reading, listening practice, conversation, writing and mock tests; (2) FCE - reading, writing, use of English, listening practice, conversation, vocabulary and mock test; and (3) CAE - reading, writing, use of English, listening practice, conversation practice, vocabulary and mock test.

\section{Method}

The main objective of this study was to investigate the possibilities and limitations of the MEO course and its potential as an educational tool for learning English in the inverted classroom format. In order to achieve this goal, a mixed methods design (DÖRNYEI, 2007) was used in the study with quantitative and qualitative data. Regarding quantitative data, 289 participants (95.5\% undergraduate students in a Brazilian federal university and 5.5\% staff of the same university) studying English at MEO course as part of the English without Borders program were asked to 
evaluate the software in terms of its usability characteristics. The age of participants ranged from 17 to 62 years, with an average of 28.52 years, SD $=9.32$ years. With regard to qualitative data, three participants enrolled in an undergraduate course of a Federal Institute of Education, Science and Technology, who were also enrolled in MEO course, were interviewed.

Data collection instruments comprised a questionnaire (for the quantitative data) and a semi-structured interview for the qualitative data. Both data collection instruments were administered in the participants' native language (Brazilian Portuguese) and the interview was transcribed and translated for analysis. The questionnaire consisted of eighteen ergonomic criteria (see FINARDI; PREBIANCA; SCHMIT'T; ANDRADE, 2014) and was administered to assess students' perception regarding the humancomputer interaction of the software as well as its usability aspects in a Likert scale of four levels of evaluation with the following options: does not meet criterion (1), partially meets criterion (2), meets criterion (3) and fully meets criterion (4). The questionnaire was sent to students by email and was also made available on the researchers' Facebook page, where they are friends with a Facebook group of MEO students. The data were submitted to a descriptive statistical analysis in order to observe the frequency of student evaluations for all evaluated ergonomic criteria.

At the end of the period for questionnaire administration, which occurred between the months of January and March 2015, three students of MEO were selected for a semi-structured interview in participants' L1 (Brazilian Portuguese), conducted for the purpose of data triangulation, which might support the statistical analysis. The interview was recorded and transcribed for analysis. The following section presents the results and the discussion of the main findings in the light of the possibilities and limitations of MEO for learning English in the inverted classroom format.

\section{Results and discussion}

Table 1 reports the distribution of students in the course by level, at the time of data collection. 
TABLE 1

Students' level on MEO. UFES, 2015.

\begin{tabular}{c|c}
\hline Course Level & Percentage of students \\
\hline I & 21.5 \\
II & 26.6 \\
III & 16.6 \\
IV & 22.1 \\
V & 13.1 \\
\hline Total & 100 \\
\hline
\end{tabular}

Source: research data

As can be seen in Table 1, most of the study participants were attending the beginner or intermediate levels of the MEO when data collection took place, with only about $35 \%$ of the sample in the last two levels of the MEO course. This result may have influenced the ergonomic analysis, since the software may have different configurations and features as its users move on to more complex levels. It is possible to suggest that thinking patterns and mental representations of more experienced users are different from first-time users regarding the learning process mediation carried out by the software (FEUERSTEIN, 1997; PREBIANCA; VIEIRA; FINARDI, 2014b).

The statistical analysis conducted to observe the frequency of student evaluations regarding the human-computer interaction usability criteria of MEO software displayed in Table 2 shows that among the 18 criteria considered, the criterion of Informational Density was the best rated by students, with $76.8 \%$ of the participants pointing out that the software "meets" or "fully meets" this criterion.

The Informational Density criterion refers to the fact that the software displays only necessary data and information on the screen, that is, indispensable information for the user to perform a certain task without a large number of windows (and/or other information), which may cause distraction and overload on memory and attention. With regard to the L 2 learning process, from a cognitive point of view, some schools advocate the importance of keeping the learner's attention focused on specific aspects of the task, without which the performance of the student may be penalized in terms of accuracy, fluency and complexity (SKEHAN; FOSTER, 2001; ROBINSON, 2001; FINARDI; PREBIANCA, 2006; PREBIANCA; D’ELY, 2008). 
For Robinson (2001), task difficulty is linked to differences in learning style as well as learners' ability and motivation and possibly the amount of stimuli involving the learning environment in which the task is performed. In the case of the tasks for learning English available in MEO, we believe that the degree of difficulty can be influenced by the presence of unnecessary incentives and information during task execution, which would lead to an overload of the student's cognitive system, affecting performance. Although the study participants have positively assessed the Informational Density criterion of MEO, we believe that the software could take into account learners' styles, cognitive capacity and needs, reducing possible negative effects associated with the quantity and quality of Informational Density of the software if it were used in the inverted classroom format.

The worst rated criteria in regards to the usability assessment considering the "does not meet criterion" level of the scale were Flexibility (43.6\%) and User Experience (27.0\%). The Flexibility criterion involves the possibility of the software to allow the user to adapt the system interface to their particular needs, such as customizing the screens by changing colors, fonts, document format, and other settings. The User Experience criterion refers to the software allowing a task to be made in different ways, taking into account the level of user experience and providing various ways of presenting the same information to different types of users: beginners and more experienced ones, also allowing experienced users to replace the use of the mouse for commands or keyboard shortcuts, for example.

Both criteria, in a way, refer to aspects of the software that are specifically under user control, compared with the other criteria evaluated in this study. This is probably one of the reasons why these criteria were evaluated in a similar way, corroborating data already demonstrated in Finardi, Prebianca, Schmitt and Andrade (2014) and Prebianca, Vieira and Finardi (2014b). We also recall that, as suggested by Robinson (2001), these two criteria relate to the learning style, and the fact that they were poorly evaluated by participants in this study points to a possibility of using MEO in the form of the inverted classroom, in which users would have more flexibility and autonomy (User Experience). We will return to this issue later on in this paper.

Still regarding the data in Table 2, it can be seen that the other evaluation criteria obtained a uniform rating, ranging between $49.1 \%$ and $73.7 \%$ of the assessments in the "meets" or "fully meets" levels of usability and human-computer interaction characteristics of the software analyzed. 
TABLE 2

MEO usability evaluation. UFES, 2015.

\begin{tabular}{l|c|c|c|c}
\hline Criterion & \multicolumn{3}{|c}{ Percentage of evaluations for each level on the Likert scale } \\
\cline { 2 - 5 } & $\begin{array}{c}\text { \% does not } \\
\text { meet the } \\
\text { criteria }\end{array}$ & $\begin{array}{c}\text { \% partially } \\
\text { meets the } \\
\text { criteria }\end{array}$ & $\begin{array}{c}\text { \% meets } \\
\text { the criteria }\end{array}$ & $\begin{array}{c}\text { \% fully } \\
\text { meets the } \\
\text { criteria }\end{array}$ \\
\hline 1. Promptness & 6.9 & 29.4 & 51.9 & 11.8 \\
\hline 2. Grouping by location & 8.0 & 24.9 & 49.8 & 17.3 \\
\hline 3. Grouping by format & 8.7 & 29.4 & 50.9 & 11.1 \\
\hline 4. Feedback & 9.7 & 23.5 & 46.0 & 20.8 \\
\hline 5. Readability & 6.2 & 20.1 & 53.3 & 20.4 \\
\hline 6. Concision & 5.9 & 24.9 & 50.5 & 18.7 \\
\hline 7. Minimal actions & 6.9 & 21.5 & 54.3 & 17.3 \\
\hline 8. Informational density & 3.5 & 19.7 & 51.2 & 25.6 \\
\hline 9. Explicity actions & 6.6 & 22.5 & 54.7 & 16.3 \\
\hline 10. User control & 8.0 & 27.3 & 48.1 & 16.6 \\
\hline 11. Flexibility & 43.6 & 21.5 & 31.5 & 3.5 \\
\hline 12. User experience & 27.0 & 33.6 & 34.6 & 4.8 \\
\hline 13. Error protection & 16.6 & 29.4 & 41.9 & 12.1 \\
\hline 14. Error message & 15.6 & 35.3 & 39.8 & 9.3 \\
\hline 15. Error correction & 6.6 & 26.3 & 46.4 & 20.8 \\
\hline 16. Consistency & 3.5 & 22.8 & 56.7 & 17.0 \\
\hline 17. Meaning & 6.2 & 25.6 & 53.6 & 14.5 \\
\hline 18. Compatibility & 2.7 & 54.0 & 14.5 \\
\hline
\end{tabular}

In order to investigate the assessment of the usability criteria, especially of those that received the best and worst ratings, namely Informational Density, Flexibility and User Experience, the data were submitted to a second descriptive analysis, taking into account only the levels of "does not meet criterion" and "partially meets criterion" in relation to the five levels of MEO in which students were enrolled. This analysis aimed to verify whether the criteria mentioned above (and possibly others) were assessed equally or differently by users at different levels in MEO. The results of this analysis are shown in Table 3. 
TABLE 3

Evaluation on does not meet criterion and partially meets criterion on the Likert scale by course levels. UFES, 2015.

\begin{tabular}{|c|c|c|c|c|c|}
\hline \multirow{2}{*}{ Criterion } & \multicolumn{5}{|c|}{ Course level $(\%)$} \\
\hline & $\mathrm{I}$ & II & III & IV & $\mathrm{V}$ \\
\hline 1. Promptness & 40.3 & 39.0 & 35.4 & 32.8 & 31.6 \\
\hline 2. Grouping by location & 35.5 & 27.3 & 25.0 & 37.5 & 42.1 \\
\hline 3. Grouping by format & 35.5 & 35.1 & 39.6 & 37.5 & 47.4 \\
\hline 4. Feedback & 35.5 & 32.5 & 35.4 & 32.8 & 28.9 \\
\hline 5. Readability & 32.3 & 26.0 & 18.8 & 23.4 & 31.6 \\
\hline 6. Concision & 37.1 & 24.7 & 25.0 & 28.1 & 44.7 \\
\hline 7. Minimal actions & 32.3 & 24.7 & 29.2 & 32.8 & 21.1 \\
\hline 8. Informational density & 33.9 & 24.7 & 18.8 & 15.6 & 21.1 \\
\hline 9. Explicity actions & 37.1 & 24.7 & 27.1 & 25.0 & 34.2 \\
\hline 10. User control & 35.5 & 32.5 & 37.5 & 35.9 & 36.8 \\
\hline 11. Flexibility & 45.2 & 62.3 & 64.6 & 78.1 & 81.6 \\
\hline 12. User experience & 43.5 & 57.1 & 58.3 & 76.6 & 71.1 \\
\hline 13. Error protection & 45.2 & 48.1 & 39.6 & 46.9 & 50.0 \\
\hline 14. Error message & 45.2 & 51.9 & 54.2 & 51.6 & 52.6 \\
\hline 15. Error correction & 33.9 & 33.8 & 31.3 & 34.4 & 28.9 \\
\hline 16. Consistency & 40.3 & 22.1 & 18.8 & 25.0 & 23.7 \\
\hline 17. Meaning & 43.5 & 31.2 & 22.9 & 21.9 & 42.1 \\
\hline 18. Compatibility & 37.1 & 33.8 & 29.2 & 25.0 & 31.6 \\
\hline
\end{tabular}

According to the data reported in Table 3, the criteria of Flexibility and User Experience did not receive a good evaluation, confirming the initial analysis reported earlier in this study. However, it can be seen that the percentage of responses in the levels of "does not meet criterion" and "partially meets criterion" is greater at the higher levels of the course. In contrast, the Informational Density criterion was rated best at the higher levels of the course.

What these data seem to show is that users with more experience are more sensitive to aspects of human-computer interaction compared to less experienced users with regard to the software flexibility and user autonomy. The data also suggest that the Informational Density criterion seems to 
affect less experienced users more, perhaps because users in initial levels of learning have less automatized linguistic knowledge and therefore more difficulty to judge certain criteria of human-computer interaction that can influence the performance on the tasks proposed by the software.

Based on Prebianca, Vieira and Finardi (2014a,b) and Finardi, Prebianca, Schmitt and Andrade (2014), and following this same line of reasoning, it was expected that the criterion of Feedback would present a worse assessment by students in the most advanced levels of the course, since they are more proficient and would have greater linguistic knowledge to assess this criterion, especially if the software provides an overview of activities undertaken by the students, including their successes and mistakes.

Prebianca, Vieira and Finardi (2014b) and Finardi, Prebianca, Schmitt and Andrade (2014) have pointed the need for educational software programs, especially focusing on teaching and learning of English, to combine pedagogical features of usability in human-computer interactions to ensure learning when it comes to providing feedback to users about the tasks (activities) carried out in the system. According to the authors of these studies, only a technical feedback does not suffice for structural cognitive modifiability to happen (FEUERSTEIN, 1997). Thus, if the software does not allow students to know their mistakes and, above all, how to fix them, they may fossilize errors, thus hampering learning.

Although the ergonomic criterion of Feedback was in general favorably rated by the participants of this study, qualitative data revealed some inconsistencies in relation to pedagogical feedback. A semi-structured interview was conducted with three students attending different levels of $\mathrm{MEO}$ in order to triangulate the data and confirm the analysis of quantitative data, supporting the argument that there must be a combination of ergonomic and pedagogic features for the software to ensure language learning. The perceptions of participants (named A, C and M) are shown in Chart 1. 


\section{CHART 1}

Excerpts from semi-structured interview about MEO: criterion Feedback

\begin{tabular}{|c|c|}
\hline Researcher's questions & Participants' answers \\
\hline $\begin{array}{l}\text { How is the quality of the feedback that the software } \\
\text { provides to you every time you do an activity, or insert any } \\
\text { incorrect answer, etc? How good is the software feedback? }\end{array}$ & $\begin{array}{l}\text { M: I think the problem is that some parts already } \\
\text { have answers but others are lacking them. For } \\
\text { example, we recorded some audio there and } \\
\text { wrote descriptive answers that were not corrected } \\
\text { yet, and it's been a while... } \\
\text { C: The activity we recorded, we are waiting for } \\
\text { their feedback and there is none, and in the test } \\
\text { the activities and pronunciation are not corrected } \\
\text { either. } \\
\text { A: Yes, I have not accessed the website very much } \\
\text { since I realized that the speech recordings are not } \\
\text { corrected or that it takes longer than expected. }\end{array}$ \\
\hline $\begin{array}{l}\text { But in relation to this feedback, do you believe that only } \\
\text { the technical feedback helps in learning or do you need to } \\
\text { bave a feedback like, "look, you made a mistake here, you } \\
\text { need to improve there", pointing out errors and what to } \\
\text { do, especially in the parts for which you said you bave not } \\
\text { received feedback, yet. }\end{array}$ & $\begin{array}{l}\text { A: Yes, it would be better if someone could direct } \\
\text { us, not the software, maybe look at our answers } \\
\text { to see if we are having difficulties. } \\
\text { C: Or maybe the software itself could do that } \\
\text { with some sort of intelligence... } \\
\text { A: Yes, to check if we are wrong. } \\
\text { C: Yes, to check our errors and give us } \\
\text { instructions and point out the repetition of } \\
\text { errors, that would help. } \\
\text { C: Yes, because the software doesn't have it right? } \\
\text { Only right or wrong. } \\
\text { M: Yes, it shows whether you made a mistake, } \\
\text { but even so it does not show how often your are } \\
\text { making that mistake [...]. }\end{array}$ \\
\hline
\end{tabular}

As we can see in the transcripts of semi-structured interviews, participants agree that the feedback provided by the software is limited and it would be better if this feedback could have a more pedagogical orientation. Participant $C$ also suggested the implementation of artificial intelligence mechanisms, which could give the software the ability to interpret the errors and suggest solutions to the problems presented. Considering the difficulty of implementing artificial intelligence techniques, we believe, based on the data reported so far, that a blended methodology implemented through the use of $\mathrm{MEO}$ in an inverted classroom mode would allow more systematic monitoring of errors, promoting moments for knowledge restructuring, and thus, language learning. 


\section{Also regarding triangulation of data, Chart 2 presents the perceptions of participants in relation to the development of the productive skills of L2 speaking and writing.}

\section{CHART 2}

Excerpts from semi-structured interview on productive skills in MEO

\begin{tabular}{|l|l|}
\hline \multicolumn{1}{|c|}{ Researcher's questions } & \multicolumn{1}{|c|}{ Participants' answers } \\
\hline $\begin{array}{l}\text { But in relation to the listening and speaking activities, } \\
\text { for example? }\end{array}$ & $\begin{array}{l}\text { M: It affects it very negatively. } \\
\text { M: There is no feedback. }\end{array}$ \\
\hline $\begin{array}{l}\text { Do you think that the lack of feedback does not represent } \\
\text { a problem for learning? }\end{array}$ & $\begin{array}{l}\text { M: No! It is a great problem! } \\
\text { A: Yes, because we do not know how to correct } \\
\text { it and if we are doing it right. } \\
\text { M: Yes, it really lacks feedback and I don't know } \\
\text { if they will correct the activities in the end. And } \\
\text { I think that it is a big mistake because if we } \\
\text { start making a mistake in the first unit and it is } \\
\text { corrected in the end, we will carry out the other } \\
\text { activities with the same mistakes and that activity } \\
\text { will be scored zero until they correct it. }\end{array}$ \\
$\begin{array}{l}\text { A: So far, we have received no feedback, so we } \\
\text { don't know if we got the audio right and how the } \\
\text { feedback will be. } \\
\text { M: But I am almost in the end. } \\
\text { M: Nothing, and I am almost in the end... Each } \\
\text { level is divided into three sublevels and each } \\
\text { sublevel is divided into 8 weeks, at least that's how } \\
\text { it is in mine. And you see I am in the end, there } \\
\text { is one week lacking to finish the course and I still } \\
\text { haven't received any feedback, neither for the } \\
\text { audio nor for the descriptive activity. }\end{array}$ \\
\hline
\end{tabular}




\begin{tabular}{|c|c|}
\hline $\begin{array}{l}\text { So the main problem is in relation to the productive } \\
\text { activities such as speaking and writing, is that correct? }\end{array}$ & $\begin{array}{l}\text { C: Yeap. } \\
\text { M: Yes, I don't know if the grade will affect it } \\
\text { in the end. I don't think so, I think there will be } \\
\text { just a final test in the end and I think it is even } \\
\text { possible to skip a few activities. } \\
\text { C: No, but in terms of learning, we are at loss } \\
\text { because of that... } \\
\text { M: Yeah, we lose. } \\
\text { C: ... you do the first week, and you record the } \\
\text { theme of that week in audio and then go to the } \\
\text { next week. [...] If they only correct it in the end, } \\
\text { things from week one, you will have to go back. } \\
\text { M: Yes, as I said before. } \\
\text { C: I think learning is affected by that because } \\
\text { there is no answer about the theme you are } \\
\text { working on. } \\
\text { C: Sometimes you keep making the same } \\
\text { mistakes and bringing them forward with you. } \\
\text { C: For example, if you learned the verb to be } \\
\text { wrong, you will use it wrong in all the activities } \\
\text { after that. If you are not corrected in the } \\
\text { beginning, you keep making the same mistake } \\
\text { and bringing it with you till the end. } \\
\text { C: Yes it does create fossilization, doesn't it? } \\
\text { M: I agree, as I said, if you don't correct it in } \\
\text { the beginning, what can you do? How can we } \\
\text { improve if we don't know what is right and } \\
\text { wrong? }\end{array}$ \\
\hline
\end{tabular}

As can be seen in Chart 2, the development of productive skills (writing and speaking), is one of the largest problems of the software, as reported in Finardi, Prebianca, Schmitt and Andrade (2014), and it seems to relate to the notion of feedback as this is necessary for the user to notice the gaps in their production (SWAIN, 1985; SKEHAN, 1998) in order to advance in the learning process. A major concern of at least two of the interviewed students refers to the risk of fossilization of errors. In other words, not knowing if their writing and speech production are correct may contribute to a false impression that there are no errors, which, in turn, can lead to the persistence of errors in future performances. The lack of pedagogical feedback can easily contribute to the stagnation of the learning process, preventing the restructuring of previously acquired knowledge. 
One way to avoid and/or minimize the fossilization of errors in oral and written productions would be to use $\mathrm{MEO}$ in the form of the inverted classroom. In this context, $\mathrm{MEO}$ would be the central technology resource of regular classes while the basics of the units could be worked remotely. That is, in the classroom, under the mediation and guidance of the teacher, students would devote time to practice oral and written skills, ask questions and interact to improve their communication skills while they work on the acquisition of grammar rules and vocabulary on their own pace and styles at home, in the distance mode.

Participants were also asked about what it would take to overcome the limitation of MEO regarding the pedagogical feedback of productive activities. The data regarding this question is reported in Chart 3.

\section{CHART 3}

Excerpts from semi-structured interview on improvements to the productive skills in MEO

\begin{tabular}{|c|c|}
\hline Researcher's questions & Participants' answers \\
\hline $\begin{array}{l}\text { And what would you suggest then for this limitation, to } \\
\text { solve this limitation of the software? }\end{array}$ & $\begin{array}{l}\text { M: Correction in a timely fashion. } \\
\text { M: Maximum five days, I think. } \\
\text { A: I think there are not enough people to listen } \\
\text { and give feedback. } \\
\text { C: I think it should be like it is with the activities, } \\
\text { they should give us weekly reports and feedback. } \\
\text { A: Or maybe every two weeks, at least for the } \\
\text { audio. }\end{array}$ \\
\hline $\begin{array}{l}\text { But do you think that it would be enough, that is, that you } \\
\text { don't need real-time help of a professional? Do you think } \\
\text { it could all be done in the distance mode? }\end{array}$ & $\begin{array}{l}\text { M: I think that if the course offered this type of } \\
\text { feedback, it would be a really nice course. } \\
\text { C: I use another software or app that does that, it } \\
\text { tells you the main errors at the end of each unit. } \\
\text { C: (...) and on the most frequent errors, the } \\
\text { software does that, it is very interesting. }\end{array}$ \\
\hline $\begin{array}{l}\text { Do you know that in some public institutions the } \\
\text { government has also established the NucLi? What is the } \\
\text { NucLi? It is in-person MEO, that is, students enroll in } \\
\text { MEO butperiodically (...) a number of students can have } \\
\text { face-to-face classes. Do you think it would help? Regarding } \\
\text { learning, I mean? }\end{array}$ & $\begin{array}{l}\text { M: Yes, they would have to correct the audio } \\
\text { anyway. } \\
\text { C: That would be great because we could correct } \\
\text { the audios in class. } \\
\text { C: Besides, we could practice conversation in the } \\
\text { NucLi because this is something we can't do in } \\
\text { MEO as it is. } \\
\text { C: Yes, to really develop conversation, we need } \\
\text { that. }\end{array}$ \\
\hline
\end{tabular}


As can be seen in the speeches of the participants in Table 3, although the possibility of a tutor or teacher working in the form of inverted classroom in partnership with $\mathrm{MEO}$ was not explicitly mentioned, the suggestions of the participants with regard to overcoming limitations on productive skills seems to point to this conclusion. We can see that the participants suggest that the lack of real-time correction and interaction is a limitation of the software and, according to our evaluation, this limitation could be offset by the teacher's mediation in the inverted classroom format. Chart 4 presents the views of students on the most disadvantaged skills with the lack of pedagogical feedback of MEO.

\section{CHART 4}

Excerpts from semi-structured interview on skills most affected by the lack of pedagogical feedback of MEO

\begin{tabular}{|c|c|}
\hline Researcher's questions & Participants' answers \\
\hline $\begin{array}{l}{[\ldots] \text { which ability is the most difficult to develop in } M E O} \\
{[\ldots] \text { ? }}\end{array}$ & $\begin{array}{l}\text { C: Pronunciation. } \\
\text { M/A: Yes, pronunciation. } \\
\text { M: Which is the most important. } \\
\text { C: Speaking and pronunciation. } \\
\text { M: Yes. } \\
\text { M: Yes, I don't know how it is in other levels, but } \\
\text { in mine there is a lot of writing. } \\
\text { A: Yes, but in writing we practice more because } \\
\text { there are many exercises. } \\
\text { M: But only words, not whole sentences, and we } \\
\text { have to make whole sentences there. }\end{array}$ \\
\hline Writing too, right? & $\begin{array}{l}\text { C: The writing not so much, because we have } \\
\text { videos and grammar rules and we can correct } \\
\text { it, but in speaking, you think you are right and } \\
\text { fossilize [the errors] because you cannot correct } \\
\text { your own pronunciation. }\end{array}$ \\
\hline $\begin{array}{l}\text { But is it only the pronunciation that is important? And } \\
\text { everything you... the whole communication situation, } \\
\text { even if you do not pronounce exactly as it is supposed } \\
\text { to be, } 100 \% \text { ? But what is more important, is it to } \\
\text { pronounce the words } 100 \% \text { correctly or to actually be able } \\
\text { to communicate, convey your message? }\end{array}$ & $\begin{array}{l}\text { A: Yes! } \\
\text { M: Both are important, but being able to } \\
\text { communicate is more. But we don't know if we } \\
\text { can communicate because there is no feedback. } \\
\text { A: Exactly, communication is compromised. } \\
\text { M: I think that the lack of teacher correction } \\
\text { affects learning, we only have descriptive } \\
\text { activities with no feedback. }\end{array}$ \\
\hline
\end{tabular}


As we can see in Chart 4, although the productive skills (speaking and writing) are recognized as being the most affected by the lack of pedagogical feedback of the software, the ability to speak in L2 is the most penalized, according to the perceptions of the participants of this study. This result corroborates those already reported in Finardi, Prebianca, Schmitt and Andrade (2014), who concluded that speaking was the most difficult skill to develop in the MEO course.

As for the written production, participants also emphasized the need for correction on improving this skill, since writing more complex texts requires more knowledge than that required for writing simple sentences to answer the optional questions in MEO. Keeping in mind the discussion so far, we strongly believe that the pedagogical feedback of the tutor or teacher in the inverted classroom mode can be an important option to compensate for the limitations of MEO regarding the productive skills found in this and in the other studies reported here.

\section{Final remarks}

Given the results of the present study, especially after the triangulation of quantitative and qualitative data, it is possible to conclude that there seems to be an extensive potential for MEO for the teaching and learning of English in the form of the flipped classroom. The assessment of the humancomputer interaction features of MEO regarding the Flexibility, Feedback and User Experience criteria has emerged as evidence for the implementation of MEO in this modality, since important aspects for the improvement of productive skills such as writing and speaking could be better handled in face-to-face classes with pedagogic mediation and feedback.

Regarding the Flexibility and User Experience criterion, MEO, when used in the form of inverted classroom, could allow users to exercise their flexibility and autonomy in performing the tasks, thus respecting the learning styles of each student. The criterion of Feedback would also have to be improved both from the ergonomic and the pedagogical point of view so as to guarantee the necessary knowledge restructuring that leads to learning and to provide room for speaking and writing improvement. In both cases, we believe feedback could be given by tutors and teachers in the flipped classroom modality, allowing the online learning platform (MEO) to be more effectively used to build L2 syntactic, grammatical and lexical knowledge. 
In order to suggest some ways to adapt this course to the flipped classroom modality, we adapt the suggestion in León, White, White and Dickens (2015) for the training of teachers and/or tutors to guarantee teacher "presence" in the distance mode, which seems to be lacking in MEO. These teachers/tutors could make the following actions in the inverted classroom mode: 1) connecting the learning community; 2) providing links to appropriate contents and pedagogical feedback; 3) promoting learning in conversations, enabling real interaction in L2; 4) encouraging the development of external networks and 5) producing weekly reports with suggestions for research and possibilities within the course.

As it is, MEO seems to be an important tool to democratize the teaching and learning of English in Brazil, but we believe it can be improved. To make it a more relevant tool for the development of English proficiency, especially in terms of speaking and writing, we suggest it is used in the flipped classroom format, where it seems to fit in perfectly.

\section{References}

BJORKLUND, S.; SUNI, I. The Role of English as L3 in a Swedish Immersion Programme in Finland: impacts on language teaching and language relations. In: CENOZ, J.; JESSNER, U. (Ed.). English in Europe: the Acquisition of a third language. Multilingual Matters: Bilingual Education and Bilingualism 19, Series Editors Nancy Hornberger and Colin Baker, 2000. p. 198-221.

CSILLAGH, V. Global trends and local realities: Lessons about economic benefits, selves and identity from a Swiss context. Studies in Second Language Learning and Teaching. Forthcoming.

DÖRNYEI, Z. Research methods in applied linguistics: Quantitative, qualitative, and mixed methodologies. Oxford: Oxford University Press, 2007.

FEUERSTEIN, R.; FEUERSTEIN, S. Mediated Learning Experience: a theoretical review. In: Feuerstein, R.; Klein, P. S.; Tannenbaum, A. J. Mediated Learning Experience (MLE): theoretical, psychosocial and learning implications. London: Freud Publishing House, 1994. p. 3-51.

FEUERSTEIN, R. Teoria de la modificabilidad cognitiva estructural. In: FEUERSTEIN, Reuven et al. Es modificable la inteligencia? Madrid: Bruño, 1997. p. 11-23.

FINARDI, K. R.; PREBIANCA, G. V. V.; MOMM, C. F. Tecnologia na Educação: o caso da internet e do inglês como linguagens de inclusão. Cadernos do IL, v. 1, p. 193-208, 2013. 
FINARDI, K. R.; PORCINO, M. C. Tecnologia e metodologia no ensino de inglês: impactos da globalização e da internacionalização. Ilha do Desterro, v. 66, p. 239-284, 2014.

FINARDI, K. R.; PORCINO, M. C. Internet tools in the design of a task cycle for L2 teaching. Revista (Con)Textos Linguísticos (UFES), v. 7, p. 273-291, 2013.

FINARDI, K. R. Technology and L2 learning: Hybridizing the curriculum. In: CONGRESSO INTERNACIONAL ABRAPUI, III, 2012, Florianópolis. Language and Literature in the Age of Technology- Anais... Universidade Federal de Santa Catarina. BECK, M. S.; SILVEIRA, R.; FUNCK, S. B.; XAVIER, R. P. (Orgs.). Florianopolis: Universidade Federal de Santa Catarina, 2012. v. 1. p. 1-8.

FINARDI, K. R.; PREBIANCA, G. V. V. Working memory capacity and speech production in L2: evidence from a picture description task. Revista de Estudos da Linguagem, v. 14, p. 231-260, 2006.

FINARDI, K. R.; PREBIANCA, G. V. V.; SCHMITT, J.; ANDRADE, D. F. Technology, English Language Teaching and Internationalization at a crossroad: insights from the analysis of a virtual learning environment in Brazil. In: INTERNATIONAL CONFERENCE OF EDUCATION, RESEARCH AND INNOVATION, 2014, Sevilha. Proceedings... Madri: IATED, 2014. v. 1. p. 1-12.

FINARDI, K. R.; TEIXEIRA, D.; PREBIANCA, G. V. V.; DOS SANTOS JÚNIOR, V. P. Information Technology and Communication in Education: two sides of the coin in Brazil. International Journal of Recent Contributions from Engineering, Science \& IT (iJES), v. 2, p. 21-25, 2014.

GRAHAM, C. R. Blended learning systems: definition, current trends, future directions. In: BONK, C. J.; GRAHAM, C. R. (Ed.). Handbook of blended learning: global perspectives, local designs. San Francisco, CA: Pfeiffer Publishing, 2005. p. 2-21.

HOFFMANN, C. The spread of English and the Growth of Multilingualism with English in Europe. In: CENOZ, J.; JESSNER, U. (Ed.). English in Europe: the acquisition of a third language. Multilingual Matters: Bilingual Education and Bilingualism 19, Series Editors Nancy Hornberger and Colin Baker, 2000. p.1-21. IACTU, T. Teaching English as a Third Language to Hungarian-Romanian Bilinguals. In: CENOZ, J.; JESSNER, U. (Ed.). English in Europe: the acquisition of a third Language. Multilingual Matters: Bilingual Education and Bilingualism 19, Series Editors Nancy Hornberger and Colin Baker, 2000. p. 236-247.

LAGE, M. J.; PLATT, G. J.; TREGLIA, M. Inverting the classroom: A gateway to creating an inclusive learning environment. The Journal of Economic Education, v. 31, n. 1, p. 30-43, 2000. 
LASAGABASTER, D. Three Languages and Three Linguistic Models in the Basque Educational System. In: CENOZ, J.; JESSNER, U. (Ed.). English in Europe: the acquisition of a third Language. Multilingual Matters: Bilingual Education and Bilingualism 19, Series Editors Nancy Hornberger and Colin Baker, 2000. p. 179-197. LEON, U.; WHITE, S.; WHITE, S.; DICKENS, K. Mentoring at scale: MOOC mentor interventions towards a connected learning community. 2015. Available at: < http://eprints.soton.ac.uk/373982/7/Mentoring $\% 20$ at $\% 20$ Scale $\% 20$ final. pdf $>$. Cited: May 19, 2015.

MUÑOZ, C. Bilingualism and Trilingualism in School Students in Catalonia. In: CENOZ, J.; JESSNER, U. (Ed.). English in Europe: the acquisition of a third language. Multilingual Matters: Bilingual Education and Bilingualism 19, Series Editors Nancy Hornberger and Colin Baker, 2000. p. 157-178.

PREBIANCA, G. V. V.; CARDOSO, G. L.; FINARDI, K. R. Hibridizando a Educação e o Ensino de Inglês: questões de inclusão e qualidade. Revista do GEL, v. 11, p. 47-70, 2014.

PREBIANCA, G. V. V.; D'ELY, R. EFL Speaking and Individual Differences in Working Memory Capacity: Grammatical Complexity and Weighted Lexical Density in the Oral Production of Beginners. Signótica (UFG), v. 20, p. 335-366, 2008.

PREBIANCA, G. V. V.; FINARDI, K. R.; CARDOSO, G. L. Ensino-aprendizagem em contextos híbridos: o que pensam os alunos sobre o uso da tecnologia em aulas de inglês no Ensino Médio Integrado. Caminhos em Linguística Aplicada, v. 12, p. 95-119, 2015.

PREBIANCA, G. V. V.; VIEIRA, M. F. V.; FINARDI., K. R. Instrução gramatical na era da tecnologia: investigando diferentes abordagens para o ensino-aprendizagem de Inglês no Ensino Médio Integrado. Signum. Estudos de Linguagem, v. 17, p. 181-214, 2014a.

PREBIANCA, G. V. V.; VIEIRA, M. F. V.; FINARDI, K. R. Assessing EFL learners' perceptions on the use of an educational software for English learning: an analysis of pedagogic and ergonomic features. Educación y Tecnología, v. 3, p. 43-62, $2014 b$

ROBINSON, P. Task complexity, task difficulty, and task production: Exploring interactions in a componential framework. Applied linguistics, v. 22, n. 1, p. 27-57, 2001.

SKEHAN, P; FOSTER, P. Cognition and tasks. Cognition and second language instruction, p. 183-205, 2001.

SKEHAN, P. A Cognitive Approach to Language Learning. Oxford Applied Linguistics. England, United Kingdom: Oxford University Press, Great Clarendon St., Oxford OX2 6DP, 1998. 
SILVEIRA, N. Hibridizando o Ensino de Inglês na Escola de Aprendizes Marinheiros do Espirito Santo. 2015. Dissertação (Mestrado em Letras) - Universidade Federal do Espírito Santo, Vitória, 2015.

SWAIN, M. Communicative competence: Some roles of comprehensible input and comprehensible output in its development. Input in second language acquisition, v. 15, p. 165-179, 1985.

TEIXEIRA, D.; FINARDI, K. R. Tics no ensino presencial: evidências de um curso de formação continuada na Universidade Federal do Espírito Santo. Revista (Con)Textos Linguísticos (UFES), v. 7, p. 79-96, 2013.

TILIO, R. Língua Estrangeira Moderna na Escola Pública: possibilidades e desafios. Educação \& Realidade, Porto Alegre, v. 39, n. 3, p. 925-944, jul./set. 2014. Available at: < http://www.ufrgs.br/edu_realidade> .

YTSMA, J. Trilingual Primary Education in Friesland. In: CENOZ, J.; JESSNER, U. (Ed.). English in Europe: the acquisition of a third language. Multilingual Matters: Bilingual Education and Bilingualism 19, Series Editors Nancy Hornberger and Colin Baker, 2000. p. 222-235

XHAFAJ, D. C. P.; PREBIANCA, G. V. V. Como produzimos a fala?. Revista da UNIFEBE, v. 4, p. 71-81, 2006.

Data de submissão: 28/05/15. Data de aprovação: 10/08/15. 